\author{
Arleta Galant \\ Instytut Literatury i Nowych Mediów, Uniwersytet Szczeciński
}

\title{
Biograf, czyli kto? Spór o Kapuścińskiego non-fiction
}

\section{Biograf (nie)nowoczesny}

Zacznijmy od końca. W posłowiu do drugiego wydania Kapuścińskiego non-fiction, a więc w 2017 roku, Piotr Bratkowski [2017: 11003] napisał m.in., że Artur Domosławski „ustanowił w Polsce nowe standardy biografistyki”. Nie był to pogląd autorski, odosobniony publicysta współdzielił go z wieloma innymi czytelnikami biografii Kapuścińskiego, którzy zabierali głos w publicznej dyskusji dotyczącej książki, wznieconej siedem lat wcześniej, po jej premierze w marcu 2010 roku [Domosławski 2010].

Piotr Mucharski [2010] w „Tygodniku Powszechnym” pisał:

Nie sposób zaprzeczyć, że autor wykroczył poza przyjęte $\mathrm{w}$ Polsce konwencje biografii i trwale zmienil granice tego, co w niej dopuszczalne. Paradoks polega jednak na tym, że podobnych biografii o innych, nie w Polsce urodzonych wielkich postaci trochę już przeczytaliśmy. I nikt się nimi nie oburzał - przeciwnie. Można sobie wyobrazić, że gdyby dzisiaj w Polsce ukazała się podobnie napisana książka poświęcona choćby Vargasovi Llosie, to przyjęto by ją entuzjastycznie. 
Cezary Michalski i Krzysztof Tomasik podkreślali:

Domosławski nie brał udziału w „budowie realizmu socjalistycznego w literaturze”, a jednak jego biografia Kapuścińskiego pełni funkcjonalnie rolę Poematu dla dorostych Ważyka. Jest świadectwem ewidentnej odwilży w pisaniu o naszych największych. Zamiast więc na książkę Domosławskiego reagować jak Iwaszkiewicz na poemat Ważyka weźcie się państwo za pisanie własnych poematów dla dorosłych. [Michalski 2010]

Cała głośna debata sprzed kilku lat wokół książki Artura Domosławskiego Kapuściński non-fiction była jak z Boya, część zarzutów wobec autora w ogóle by nie padła, gdybyśmy przerobili lekcję dotyczącą biografistyki zadaną przez Żeleńskiego w Brazownikach. [Tomasik 2014]

Pozostali publicyści, np. Jacek Żakowski [2010], zwracali uwagę na to, że Domosławski jako biograf „odrzucił hagiograficzną normę i potraktował Kapuścińskiego jako człowieka nie tylko wielkiego, lecz także realnego [...]. Paszkwil ani hagiografia nie powiedziałyby nam tyle o Kapuścińskim". Z kolei Irena Grudzińska-Gross [2011] wyrażała przekonanie, iż „Kapuściński non-fiction stanowił przełom $\mathrm{i}$, sądząc z reakcji czytelników, powrót do poprzedniej biograficznej poprawności nie będzie już możliwy”.

W opinii zarówno Mucharskiego, Michalskiego, jak i Tomasika, Żakowskiego, Grudzińskiej-Gross - Artur Domosławski, autor biografii cesarza reportażu, ujawnił się jako przewrotowiec, za sprawą którego polska biografistyka uległa nieodwracalnej przemianie. Gdyby zapytać o szczegółowe uzasadnienia tej ogólnej diagnozy, udałoby się wskazać nie tylko jeden z najważniejszych wątków publicznej dyskusji wokół Kapuścińskiego non-fiction, ale także jedną z istotnych, wspóltworzących ową dyskusję, osi myślenia o statusie narracji biograficznej. Narracja ta - zdawali się mówić mniej lub bardziej otwarcie recenzenci (i recenzentka) ma znaczenie interwencyjne, odsłania zacofanie, ograniczoność polskich odbiorców, stanowi dowód na nienowoczesność polskiej kultury. Tekst biograficzny zaproponowany przez dziennikarza 
„Gazety Wyborczej” należało czytać - wedle wymienionych krytyków - jako rzecz absolutnie nowatorską. Argument o nowatorstwie wspierały dwa negatywne porównania: anachronicznego rynku książki biograficznej w Polsce z progresywnym rynkiem zachodnim oraz Domosławskiego z Boyem. Miało to uświadomić, że Polacy nie podjęli dotąd koniecznego wysiłku odbrązawiania „wielkich”, a zatem nie dostrzegli wagi nierozerwalnych relacji pomiędzy prywatnym a publicznym. A przecież - dodajmy - to właśnie biografia, utwór nieliteracki, pograniczny, relacje te wydobywa, nimi się żywi, na ich podstawie buduje wizję osoby i życia.

Owe relacje wiążą się ze sprzecznościami, które jednak rzadko były przedmiotem krytyczno-publicystycznej debaty wokół Kapuścińskiego non-fiction. Znacznie więcej uwagi poświęcano kwestiom dotyczącym obowiązków i wykroczeń autora, co nie dziwi nie tylko dlatego, że uznano Domosławskiego za kogoś, kto poszerzył czy też zreformował uprawnienia biografa. Dyskusja o książce miała charakter mocno środowiskowy, została również wzmocniona pozwem złożonym przeciwko dziennikarzowi przez Alicję Kapuścińską; pozew ten - wiele na to wskazuje - silnie kształtował ton wielu ówczesnych publicystycznych wypowiedzi [Galant 2019]. W przypadku biografii słynnego reportera styk prywatnego z publicznym nie był zatem wyłącznie narracyjny, symboliczny czy - by tak rzec - ogólnoobyczajowy - dotykał konkretnych osób. W głównej mierze to właśnie z uwzględnieniem tej sytuacji próbowano ustalać aktualny stan prerogatyw autora biograficznego tekstu.

Jedną z ważniejszych perspektyw lektury biografii mistrza Ryśka była perspektywa, w ramach której ową biografię rozumiano jako wypowiedź ukształtowaną przez dyskurs medialny. O nade wszystko medialnych uwikłaniach współczesnych biografów, w tym biografa Kapuścińskiego, pisał m.in. Leszek Bugajski [2010: 99-100] na łamach „Twórczości” w tekście Prześwietlanie Kapuścińskiego:

Autor biografii byłby głupcem, gdyby w trakcie jej pisania nie kalkulował sobie, że musi się ona spotkać z zainteresowaniem wykraczającym daleko poza granice Polski [...]. U nas, wia- 
domo, narodowych świętości się raczej nie obraża [...]. Ale książka musi mieć walory komercyjne, czyli jej autor musi coś tam ujawnić z prywatnego życia bohatera, bo tych ujawnień szuka w niej tak zwany masowy czytelnik. [...] Tyle tylko, że te dwa rozdziały dotyczące prywatnego życia autora Cesarza sprawiają wrażenie sztucznie doklejonych do książki. Są jakby poza tokiem jej podstawowej narracji. [...] Takie są jednak reguły gry w tej dziedzinie. Książka jest dzisiaj towarem, którym się handluje, a tym lepsze efekty tego handlowania się osiąga, im bardziej jest ona brutalna, obsceniczna, denerwująca. [...].

Dla Bugajskiego [2010: 98-99] dyskusja, jaką wywołała publikacja Domosławskiego, pozostawała nie do końca zrozumiała, a sama książka była - w jego przekonaniu - raczej nudna. Krytyk rozważał autorskie intencje biografa oraz zasady funkcjonowania przekazów biograficznych na rynku. Wynikła z tego wszystkiego dość wykrętna ocena. Właśnie tak - wykrętna. Domosławski powiadał Bugajski - nie jest głupcem, wie, jak działa świat, i swój utwór do tego świata dostosował. Otrzymaliśmy biografię, która jest produktem, to oczywiste, banalne, ale też dzielne i śmiałe. Lekturę recenzenta napędzały rozmaite determinizmy - rynku, popularności czytelniczej, wreszcie wyjątkowej roli dziennikarza. Znamienne, że za sprawą tych determinizmów w zamierzeniu ironiczna i demaskatorska postawa krytyka uwidaczniała normalizujący język krytycznego wartościowania. W języku tym Bugajski pośrednio wyrażał przekonanie, że biograficzne pisarstwo to zajęcie dla kogoś, kto choć nie jest już wprawdzie wszechwiedzącym badaczem życia i twórczości, to jednak okazuje się niezmiennie administratorem prawdy, wszechwiedzącym podmiotem swojej pracy:

Dziennikarz jest wysłannikiem swoich czytelników w te rejony, do których oni nie mają szans dotrzeć, a czytelnicy ci to nie wyłącznie dżentelmeni i intelektualiści, ale w większości plotkarze i łowcy sensacji o ludziach skupiających na sobie powszechne zainteresowanie. [Bugajski 2010: 100]. 
$\mathrm{Z}$ jednej strony mamy więc do czynienia z kalkulacją i komercją, ale $\mathrm{z}$ drugiej strony ze szczególną misją dziennikarza, misją kontrowersyjną, lecz nastawioną na konieczne demaskacje.

$\mathrm{Na}$ stronach internetowego magazynu o kulturze popularnej „Esencja” Jakub Biły również pisał o tym, że przedsięwzięcie biografa jest w oczywisty sposób nieprzypadkowym zdarzeniem medialnym, a przy tym zdarzenie to wspóltworzy. Jednak w przekonaniu autora tekstu Przygody dobrego reportera Kapusty Domosławski nie opublikował sensacyjnego gotowca dla masy nowinkarzy, „raczej stworzył układankę zawierającą wiele dopełniających się elementów, z których każdy może ułożyć własny wizerunek Kapuścińskiego” [Biły 2010]. Wykalkulowana przez dziennikarza sensacyjność książki, którą odnotowywał krytyk w „Twórczości”, tu została ironicznie zakwestionowana:

Najwięcej wrzawy wzbudziło „wejście z buciorami” autora w cudze życie prywatne. Na początku plotka gminna głosiła, że to materiał rodem z Pudelka: zdrady, konflikty i odrzucenia! Kapuściński Tigerem Woodsem reportażu! Domosławski (1. 43) zdradzieckim klonem agenta J-23, podającym adresy, kontakty, nazwiska! Tymczasem wzmiankowane tematy poruszane są bardzo subtelnie, niemal lirycznie... co sprawia, że stanowią najsłabszą część książki. Mało konkretów i słabo zarysowane postaci żony i córki sprawiają, że te rozdziały nic nie wnoszą do wizerunku Kapuścińskiego. [Biły 2010]

Recenzent „Esencji” nie unikał jednoznacznych ocen, nie diagnozował mechanizmów marketingowych, nie uzależniał od nich lektury, dając do zrozumienia, że Kapuściński non-fiction to utwór otwarty, niesformatowany. Jeśli jednocześnie do czytelnika należą ciągi dalsze tej biografii, do czytelnika należy jej interpretacja, to kwestia dziennikarskiej prawdy czy nieprawdy nie ma znaczenia. I faktycznie, w recenzji nie roztrząsano zagadnień autorskich biograficzno-dziennikarskich powinności. Podobnie nie podejmowano tematu literackiej kreacji reportażowych dzieł mistrza, tematu, który - dopowiedzmy - dla Bugajskiego [2010: 100] stanowil ,jedyny poważny element toczonej wokół książki Domo- 
sławskiego dyskusji” i okazywał się w ujęciu krytyka przynależny dwóm niezależnym obszarom refleksji: dziennikarskiemu i literaturoznawczemu/krytycznoliterackiemu. Ten pierwszy obszar pozostawiał Bugajski [2010: 100-101] dziennikarzom, ten drugi uznawał za dostarczyciela dla siebie, jako odbiorcy reportaży Kapuścińskiego, rozpoznań rozstrzygających.

Co ważne, obie recenzje, odsyłając nas do tej samej rzeczywistości medialnej oraz eksponując medialny status współczesnej biografistyki, nie doprowadzają do podobnych wniosków. Między innymi dlatego, że Bugajski występował w roli krytyka, którego już nic nie może zaskoczyć, Biły [2010] zaś recenzenta-czytelnika, który chce zostać zaskoczony'. Albo inaczej: w przeciwieństwie do krytyka „Twórczości”, Biły był jednym z czytelników, o których się w swojej recenzji upominał, a o których nie pisał uogólniający i diagnozujący Bugajski. Ponadto ten pierwszy uważał, że biograf ma rozległe prawa, w tym prawo do budowania niewygodnych relacji z odbiorcami; ten drugi z kolei wyrażał przekonanie, że mimo medialnych umocowań biograf nie miewa gruntownej władzy nad czytelnikami.

\section{Biograf (nie)obecny}

W innych omówieniach i recenzjach Kapuścińskiego non-fiction ogniskowano uwagę na relacjach biografa nie tyle z publicznością czytelniczą, ile z bohaterem biograficznej opowieści. Urszula Glensk w szkicu Siedem grzechów Domosławskiego rozważała konsekwencje, jakie płyną ze sprzeczności ról autora książki, którego narracja okazuje się narracją przyjaciela i wroga, kolegi i wątpliwego sprzymierzeńca Kapuścińskiego.

„Można także odnieść wrażenie, że dzieje Kapuścińskiego w nowej Polsce zostały potraktowane nieco po macoszemu. A przecież dramat człowieka zmagającego się zarówno z własną przeszłością jak i wielkością zasługuje na więcej niż tylko ostatnie kilkadziesiąt stron. Jakaś część nie zagrała: może obrana metoda, może na przeszkodzie stanął fakt samej znajomości między dziennikarzami. Niewykluczone, że Kapuściński faktycznie nie ogarniał otaczającego świata, a dogłębna analiza targanego sprzecznościami człowieka była ponad siły autora” [Biły 2010]. 
Mógł być też całkiem inny powód deklaracji biografisty, że nie będzie hagiografizował, a mianowicie bliskie relacje, jakie wiązały go z domem Kapuścińskich (był tam, jak twierdzi, „dziesiątki razy”).W ten sposób chciał zamanifestować swój obiektywizm. Bo istotnie można obawiać się braku dystansu, jeśli punktem wyjścia jest osobista znajomość, a nawet przyjaźń. Z familiarnej relacji wynika dwuznaczność sytuacji badawczej, w jakiej znalazł się Domosławski, choć wybrnął z niej, minoderyjnie, przyjmując dwie perspektywy, które wzajemnie sobie przeczą - przyjacielską i demaskatorską. Autor wielokrotnie podkreśla swoją bliskość z Kapuścińskim, nazywa go przyjacielem albo mistrzem. Tak określona relacja sankcjonuje poziom wtajemniczenia: znałem, widziałem, wiedziałem. [...] Niewątpliwie przyjacielska relacja ułatwiła Domosławskiemu dostęp do materiałów. Te korzyści nie ograniczyły go ani nie powstrzymały przed sugerowaniem negatywnych ocen. [Glensk 2010]

Zdaniem krytyczki osobista wzajemna znajomość reporterów stanowi jedno ze źródeł kłopotliwych wyborów/rozwiązań warsztatowych w Kapuścińskim non-fiction. Interesujące jest to, że z wywodu Glensk, punktującej warsztatowe sprzeniewierzenia Domosławskiego, można wywieść model biografii idealnej, której zasadą główną byłoby stronienie od subiektywizacji faktów. Ale to nie wszystko. Badaczka poświęciła swoje rozważania także znaczeniom, jej zdaniem wybitnie perswazyjnych, strategii narracyjnych, w ramach których dziennikarz „Gazety Wyborczej” rozwija swój tekst o Kapuścińskim [Glensk 2010]². Wśród tych strategii znajdują

„Perswazyjność wywodów Domosławskiego widoczna jest w zamierzonych powtórzeniach. Biografista używa repetycji jako środka perswazji szczególnie w tych fragmentach, gdzie pojawia się jakiś zarzut, gdzie trzeba wyeksponować niedociągnięcie, przekłamanie. Wyjaśnia, dlaczego przypisywano reporterowi znajomość z Che Guevarą, mimo że w rzeczywistości nigdy nie spotkał rewolucjonisty. Wątek wykreowanej znajomości z ówczesnymi politykami (także z Idi Aminem czy Lumumbą) w Non-fiction powtarzany jest czterokrotnie, albo w tekście głównym, albo w przytoczeniach, albo w wypowiedziach świadków” [Glensk 2010]. 
się - powiadała badaczka - m.in. „pomijanie lub marginalizowanie świadków”, manipulowanie ich wypowiedziami, nieuwzględnianie argumentów przeciwnych w objaśnianiu danego biograficznego faktu czy „komentarze odautorskie, pełne określeń wzmagających negatywne wrażenia” [Glensk 2010]. W ujęciu Glensk wszystko to dowodzi niestaranności warsztatowej, a nawet więcej - dwuznacznych, nie do końca uczciwych intencji Domosławskiego. To oznacza, że dla krytyczki nie jest on reformatorem biografistyki, lecz autorem, który zignorował lub też złamał wiele jej reguł.

Wątek sprzeczności, a w związku z tym tendencyjności czy nieneutralności ról biografa, jest interesujący. Przez innych recenzentów książki również bywał eksponowany, ale odmiennie wartościowany. Na łamach „Więzi” Konrad Sawicki podkreślał, że role piszącego Kapuścińskiego non-fiction to przykład niezbędnych zmagań biografistycznych.

Tak jak mistrz Kapuściński swoje najlepsze teksty opierał na doskonałej obserwacji szczegółu i na tej bazie stwarzał przenikliwe syntezy, tak teraz uczeń Domosławski podąża jego śladami i Kapuścińskiego opowiada Kapuścińskim. Jest to jednak biografia niestandardowa, ponieważ ma dwóch bohaterów. Artur Domosławski w opowieść o Ryszardzie Kapuścińskim wpisuje swoją osobę i swoją przygodę z mistrzem. [...] Czytając o barwnym życiorysie najsławniejszego polskiego reportera, o jego podróżach, znajomościach, ewolucji poglądów, artykułach i książkach obserwujemy jednocześnie ewolucję myśli autora biografii. [...] Wyobrażam sobie, że ze strachem zmierzyć się musiał także Artur Domosławski. W taki sposób pisać o swoim przyjacielu i mistrzu? [Sawicki 2011: 135, 138]

Na łamach „Pograniczy” Brygida Helbig [2010: 96] wyznawała, że dla niej „niezwykle cenne są właśnie takie fragmenty, zapis procesów myślowych samego piszącego, którego perspektywę dzięki temu bardziej rozumie”. Osobiste uwikłania autora i bohatera biografii odsłaniają napięcia, które miałyby ukazywać iluzję dążenia do neutralności postawy pisarskiej, uautentyczniać narrację biograficzną, a także odróżniać ją od anachronicznego paradygmatu 
biografii pisarza. Możliwość tego odróżnienia wyznacza kolejną istotną kwestię, dotyczącą publicystycznej dyskusji wokół Kapuścińskiego non-fiction. Kiedy bowiem Glensk zarzucała Domosławskiemu tendencyjność, odwoływała się m.in. do książki Zygmunta Ziątka i Barbary Nowackiej Kapuściński. Biografia pisarza [Nowacka, Ziątek 2008], stanowiącej dla autorki szkicu, jeśli nie wzór biografii, to przykład biografii doskonalszej. Doskonalszej jak można przypuszczać - dlatego, że realizującej konwencję biografii pisarza właśnie, a więc wyzyskującej warsztat, który pozostaje warsztatem badacza, w tym konkretnym przypadku badacza literatury. To dzieło mistrza, a nie jego życie prywatne stanowiłoby o dynamice opowieści biograficznej. Domosławski - pisała Glensk, a także Ziątek [2010], zaś Agata Tuszyńska podkreślała to podczas debaty, która odbyła się w Instytucie Reportażu ${ }^{3}$ - w nieuprawniony sposób tymczasem zmarginalizował twórczość Kapuścińskiego.

Ale czy fakt, że nie mamy do czynienia z biografią pisarza, musi wiązać się z przyganą? Krzysztof Hoffman [2010: 121] w „Czasie Kultury" zaznaczał - nie ganiąc - że

Kapuściński non-fiction to książka pisana przez dziennikarza o Kapuścińskim jako dziennikarzu (reportażyście). W niczym nie umniejsza to jej rangi, zmienia natomiast optykę narracji, eksponuje elementy warsztatu, wywołuje pogoń za diagnozami, wrażenie konieczności objaśniania świata i jego bohaterów.

Jeśli krytyk formulował zarzuty dotyczące biografistycznego warsztatu Domosławskiego, to były to zarzuty dotyczące niezrozumiałego (bo też i niemożliwego do przyjęcia) przekonania biografa o przezroczystości własnego języka: wokół książki Domosławskiego Kapuściński non-fiction. Prowadzenie: Wojciech Tochman, Instytut Reportażu i Księgarnia Muzeum pro qm, 16 marca (wtorek) 2010 roku. 
Relacja fiction - non-fiction to obsesja pisarstwa Domosławskiego. Co należy do literackiej autokreacji? Czy ubarwia własną biografię? Co wolno dziennikarzowi? Biograf komplikuje te pytania, stara się wielostronnie oświetlić jedno zdarzenie, lecz prawda niezmiennie pozostaje dla niego skalpelem niezwykle ostrym. Zupełnie jakby on sam nie konstruował własnej opowieści, jakby nie pisał, lecz oddawał przezroczystym językiem istotową tkankę rzeczywistości. [Hoffman 2010: 119]

Głos Hoffmana prowokował do tego, by zwrócić uwagę na inne jeszcze zagadnienie związane z książką Domosławskiego. Można przedstawić je następująco: biograf pisze jako dziennikarz, ale to nie znaczy, że nie pisze literatury; tekst jako tekst biograficzny w związku z dziennikarskimi kompetencjami autora nie przestaje należeć do przestrzeni literatury. Można zatem powiedzieć, że nie chodzi o to, iż Domosławski wadliwie zrealizował warsztat, ale nie do końca poprawnie pojąl jego pojemność/zakres. Jednocześnie autor biografii ukazał swoją paradoksalną obecność w narracji obiektywnego, choć mocno sprywatyzowanego poszukiwacza prawdy.

W wypowiedziach publicystów, dziennikarzy i reportażystów, problemu literackości biograficznego pisania właściwie nie podejmowano. Być może to zrozumiałe, że pilniejsze okazywały się raczej pytania o literackość reportaży (Kapuścińskiego). A jednak to, jak się zdaje, nie bez znaczenia, że nierzadko stawiano Domosławskiemu jako biografowi wyraźne granice, wyrysowujące to, co dopuszczalne, i to, co niedopuszczalne w opowieści o życiu mistrza, nie roztrząsając znaczenia uporczywych deklaracji biografa o docieraniu do prawdy. Czy powodem tego nie był fakt, że publicyści relacje fiction - non-fiction porządkowali w opozycji literatury i dziennikarstwa?

\section{Biograf (nie)etyczny}

Jeśli się było Ryszardem Kapuścińskim, nie ma się prywatności w ten sposób można streścić stanowiska raczej nielicznych publicystów i krytyków, reagujących na opinie o nadużyciach biografa 
opisującego relacje słynnego reportażysty z żoną, córką, innymi kobietami. Te opinie - zaznaczmy - formułowała nieco liczniejsza grupy komentatorów książki Domosławskiego. Żakowski [2010] twierdzil, że „nie ma w książce niczego, co by [...] przekonało, że musiał się w niej znaleźć rozdział o kochankach. Jest on zbytecznym okrucieństwem wobec wdowy”. Żakowskiemu brakowało uzasadnienia, które ukazałoby słuszność podejmowania przez biografa tematów dotykających prywatnych spraw mistrza.

Dziennikarz czasem musi być okrutny wobec ludzi, których opisuje, ale musi mieć po temu bardzo dobry powód. Musi za tym przemawiać ważny publiczny interes. Ja tu dobrego powodu nie widzę

- pisał publicysta, dając do zrozumienia w dalszej części swojego wywodu, że dodatkowym warunkiem wyjawienia prywatnych szczegółów biografii Kapuścińskiego powinien być także odpowiedni moment: „Gdybym miał takie prawo, apelowałbym o usunięcie tych dwóch rozdziałów ze wznowień i zagranicznych wydań. Przynajmniej dopóki żyją ludzie, których one dotyczą i dotykają" [Żakowski 2010].

W podobnym tonie pisali o Kapuścińskim non-fiction

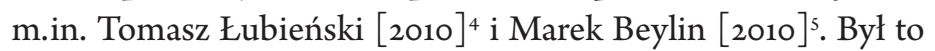
ton nie tylko krytyczny, ale i cenzurujący, moralizatorski, oceniający Domosławskiego jako człowieka. Beylin w artykule Sprawa Ryszarda K. stawiał pytanie: czy sława wyklucza empatię? Następ-

„Ale tak już było, Kapuścińskiego pasjonował świat, życie prywatne było jego prywatną sprawą. [...] Ale naprawdę drastyczna jest relacja z rozmowy z tajemniczą przez trzydzieści trzy lata przyjaciółką Kapuścińskiego, odkrytą przez autora królową jego podwójnego życia. Nie wiadomo, czy naprawdę istnieje, czy to nie mitomanka. [...] Ale nie bez racji Dante umieścił w niskim kręgu piekła tych, co nadużyli zaufania swoich przyjaciól, a za przyjaciela domu państwa Kapuścińskich uważał się podczas pracy nad książką Artur Domosławski” [Łubieński 2010].

5 „Wiem, że istnieje nurt biograficzny, w którym ujawnia się wszystkie, nawet najbardziej drażliwe szczegóły życia prywatnego. Ale nie jest to nurt obowiązujący. Zresztą biografia Kapuścińskiego nie potrzebuje tych intymności, jest i tak bogata. Zabrakło książce smaku i empatii wobec ludzi” [Beylin 2010]. 
nie, punktując złe i dobre strony książki Domosławskiego, dochodził do wniosku, że „należy szanować godność ludzi opisywanych, jeśli sami się tej godności nie pozbawili” [Beylin 2010]. Publicyście zależało na tym, aby nie urazić redakcyjnego kolegi („Szukam słów, by nie urazić Artura Domosławskiego, mojego redakcyjnego kolegi, i zarazem wyrazić oburzenie. Bo Domosławski naruszył godność żyjących w imię sensacji”); równocześnie myślał on „o uczuciach wdowy”, wobec której autor biografii postąpił niesprawiedliwie i bez empatii [Beylin 2010].

Oceny innych recenzentów i recenzentek bywały również krytyczne, jednak nie miały charakteru moralizatorsko-personalnego; odnosiły się do uchybień warsztatowych, które miały być dowodem na przekroczenie przez biografa zasad etyki zawodowej. Przypomnijmy, chodziło przede wszystkim o to, że - jak powiadali adwersarze Domosławskiego - autor ujawnił niektóre fakty wbrew woli Alicji Kapuścińskiej oraz zaniedbał obowiązek konsultacji/ rozmowy z córką mistrza [Glensk 2010; Helbig 2010]. Wdowa po pisarzu w rozmowie z Mateuszem Pilarczykiem relacjonowała:

Dostałam informacje o zawartości książki. Uzgodniłam z prawnikiem, że on się tym zajmie. Pokazał mi pozew. W tym pozwie jest wiele cytatów z książki Kapuścinski non-fiction. Każdy z nich jest opatrzony jednym ze zdań: Narusza dobra osobiste żony, córki; narusza dobrą pamięć o Kapuścińskim; narusza prawa autorskie. Wytoczyłam sprawę sądową o ochronę dóbr osobistych oraz praw autorskich, bo w książce jest dużo cytatów z dzieł męża. [...] Mój adwokat przytoczył precedens prawny z wyroku Europejskiego Trybunału Praw Człowieka, który uznał, że dobra osobiste mają pierwszeństwo przed wolnością słowa. Czytelnicy mają prawo wiedzieć, ale jest pewna granica. Nie miał prawa pisać o życiu osobistym. Nie został upoważniony do pisania o mojej córce, której nigdy nie spotkał. [Pilarczyk, Kapuścińska 2010]

Sam Domosławski twierdził z kolei, że gdyby miał napisać swoją książkę raz jeszcze, to niczego by w niej nie zmienił, a nawet „zastanawiałby się, czy wątków prywatno-osobistych nie rozsze- 
rzyć” [Majmurek, Domosławski 2017] $]^{6}$. Tymczasem opisy osobistej warstwy życia reportażysty w książce dziennikarza były niekiedy przyczyną oskarżeń totalnych, co odbywało się nie tyle w wymiarze środowiskowym (jak w przypadku stanowisk Żakowskiego i Beylina), ile światopoglądowo-politycznym. W „Tygodniku Solidarność” Grzegorz Eberhardt [2010: 19] uznawał Kapuścińskiego non-fiction za dowód niemoralności zarówno autora, jak i bohatera biografii:

Kapuściński to także mężczyzna. Mąż. Często niewierny. Fakt ten jest raczej obojętny dla środowiska autora książki, dla świata relatywizmu przecież. W którym niezdradzanie nie jest przejawem zasad, odpowiedzialności, a jedynie frajerstwa, braku wzięcia czy okazji. I dlatego też w książce jest miejsce dla bezkrytycznego przedstawienia starej znajomej bohatera, wspominającej go jako barwnego faceta. [...] Domosławski wspomina inną kochankę swojego bohatera: „Będzie miała wiele związków, zazwyczaj udanych. Faceci lgnęli do niej”. Jakie udane, jeśli... rozstane?! No, ale tej wątpliwości u kogoś związanego z tą opcją próżno by szukać! [...] Odnajdując w książce wątek rodzinny zaczynam rozumieć zastrzeżenia wdowy po autorze Cesarza. Np. szczegółowość opisu problemów lat dorosłych przekracza granice smaku. Jest także, co gorsze dla autora, wątkiem niepotrzebnym. Bo przecież nie łudzę się, że red. Domosławski chciał w ten sposób skrytykować swojego bohatera, którego to minione zachowania doprowadziły do takich komplikacji, do nienormalności w życiu najbliższych...? wątków prywatno-osobistych nie rozszerzyć. Kiedy pisałem tę książkę, w Polsce nie było zachęcających wzorców pisania biografii. Pisało się je brązowniczo. Nie wiem, z czego to wynika, w każdym razie niewiele się zmieniło, od kiedy pisał o tym Boy. Może z tego, że mamy tak mało sukcesów? Że jak ktoś już sukces odnosi - tak jak Kapuściński - to nie chcemy, by na jego wizerunku pojawiła się najmniejsza choćby rysa? Miałem wrażenie, że swoją książką robię «rozpoznanie» tego, co można powiedzieć o ważnej, historycznej postaci. Rozumiem, że różnie odbierają to ludzie z różnych pokoleń; że nie wszyscy zgadzają się co do tego, czy zachowałem takt czy nie" [Majmurek, Domosławski 2017]. 
Bardzo rzadko, ale i takie wypowiedzi się zdarzały, w miejscu uwag odwołujących się do etyki warsztatu/zawodu pojawiały się sugestie, że część książki Domosławskiego traktująca o prywatności bohatera biografii jest niepotrzebna z powodów estetycznych:

Bez rozdziałów o uczuciowych związkach Kapuścińskiego i o jego trudnych stosunkach z córką ta książka byłaby moim zdaniem, lepsza, miałaby czysty ton, ale nie byłaby takim sukcesem komercyjnym, jakim się stała. I to jest ta brutalna prawda o dzisiejszym świecie mediów. [Bugajski 2010: 99]

Równie rzadko pisano o tym, że spór o wyjawioną prywatność Kapuścińskiego należy do nie do końca umotywowanych [Biły 2010; Hoffman 2010]. Najczęściej szukano szerszych uzasadnień dla decyzji biografa „donoszącego” m.in. o romansach mistrza.

Po pierwsze zatem przekonywano, że biografia niezawierająca szczegółów z życia prywatnego swojego bohatera pozostaje tekstem wybrakowanym, niepełnym, a nawet nieuczciwym [Bratkowski 2017]. Po drugie proponowano, by potraktować gest biografa ujawniającego intymne wybory Kapuścińskiego jako gest rewizyjny. Michał Sutowski w tekście zamieszczonym w „Gazecie Wyborczej” podkreślał, że rozdziały poświęcone kobietom w życiu i twórczości reportażysty należałoby ujrzeć na szerszym tle ideowo-egzystencjalnym i historycznym. Lewicowa postawa Kapuścińskiego nie szła w parze z myśleniem feministycznym, przeciwnie - „męskie” wybory autora Imperium ukazują anachroniczny patriarchalizm epoki, w której dorastał i żył [Sutowski 2010]7. Lektura książki Domosławskiego jako całości zaprojektowanej tak, by uchwycić nie tylko polityczne, twórcze, ale i obyczajowe zmiany w życiorysie cesarza reportażu, uzasadniałaby sposób wykorzystania przez biografa informacji o pozamałżeńskich i prywatną, a zwłaszcza praktyka życiowa Kapuścińskiego w tej pierwszej - wzorem «lewicowej» męskości reportera zaangażowanego pozostaje dziś raczej larssonowski Mikael Blomqvist. Kapuściński, mówiąc nieco przewrotnie, zasługiwałby na porządną, feministyczną reedukację - choć należy mieć świadomość uwarunkowań epoki, w jakiej dojrzewal” [Sutowski 2010]. 
związkach Kapuścińskiego; potwierdzałaby także sensowność rozdziału o niełatwych relacjach Kapuścińskiego z córką. Celem Domosławskiego nie było ujawnienie prywatności, lecz próba jej krytycznego zrozumienia. Słowem: rewizyjna rama w odbiorze tej biografii miała uwypuklić, że prywatne jest polityczne.

Można uznać, że wydobycie rewizyjnego kontekstu biograficznego przedsięwzięcia Domosławskiego w pewien sposób zawieszało zarzuty o nieetyczność autora. Jednak można również odnotować, że zarzutów tych ostatecznie nie anulowało. W końcu bowiem biograf opowieść o tym, jak prywatne jest polityczne, snuje na przykładzie prywatności cudzej, nie własnej.

\section{Bibliografia}

Beylin Marek (2010), Sprawa Ryszarda K., [online], [dostęp: 6 czerwca 2018], http://wyborcza.pl/1,76842,7607361,Beylin__Sprawa_ Ryszarda_K_html.

Biły Jakub (2010), Przygody dobrego reportera Kapusty, [online], [dostęp: 28 czerwca 2018], https://esensja.pl/ksiazka/recenzje/tekst. html id $=9451$.

Bratkowski Piotr (2017), Oskarżony Domosławski, w: Artur Domosławski, Kapuściński non-fiction, Wielka Litera, Warszawa, loc. 10272-11340.

Bugajski Leszek (2010), Prześwietlanie Kapuścińskiego, „Twórczość”, nr 5, s. 97-100.

Domosławski Artur (2010), Kapuściński non-fiction, Świat Książki, Warszawa.

Eberhardt Grzegorz (2010), Odbrazawianie czy lukrowanie, „Tygodnik Solidarność”, nr 12, s. 18-19.

Galant Arleta (2019), Proporcje i rewizje. Konstelacja „Kapuścińskiego non-fiction", w: Konstelacje krytyczne, Universitas, Kraków [w druku].

Glensk Urszula (2010), Siedem grzechów Domosławskiego, [online], [dostęp: 29 września 2017], http://kapuscinski.info/siedemgrzechow-domoslawskiego.html.

Grudzińska-Gross Irena (2011), Rentgen nie zna litości, „Książki. Magazyn do Czytania”, nr 1, s. 14.

Helbig Brygida (2010), Kapuściński nie byt pluszowym misiem, „Pogranicza”, nr 2, s. 96-100.

Hoffman Krzysztof (2010), Literackie stopnie prawdy, „Czas Kultury”, nr 3, s. 118-121. 
Łubieński Tomasz (2010), Uczeń Kapuścińskiego?, [online], [dostęp: 6 czerwca 2018], http://wyborcza.pl/1,75410,7619740,Tomasz Lubienski_Uczen_Kapuscinskiego_.html.

Majmurek Jakub, Domosławski Artur (2017), Napisatbym dziś tę biografię doktadnie tak samo, [online], [dostęp: 6 czerwca 2018], krytykapolityczna.pl/kraj/domoslawski-napisalbym-dzis-tebiografie-dokladnie-tak-samo.

Michalski Cezary (2010), Poemat dla dorostych Artura Domostawskiego [cyt. za: Prasa polska o książce Kapuściński non-fiction], w: Artur Domosławski, Kapuściński non-fiction, Wielka Litera, Warszawa, loc. 11211- 11254 .

Mucharski Piotr (2010), Przybysz, [online], [dostęp: 3 czerwca 2018], https://www.tygodnikpowszechny.pl/przybysz-145368.

Nowacka Barbara, Ziątek Zygmunt (2008), Ryszard Kapuściński. Biografia pisarza, Znak, Kraków.

Pilarczyk Mateusz, Kapuścińska Alicja (2010), To jest ojcobójstwo, [online], [dostęp: 6 czerwca 2018], http://wyborcza. pl/1,76842,7625923,Alicja_Kapuscinska_To_jest_ojcobojstwo. html.

Sawicki Konrad (2011), Jedna biografia i dwóch bohaterów, „Więź”, nr 1, s. $135-138$.

Sutowski Michał (2010), Ryśka nie da się upupić, [online], [dostęp: 6 czerwca 2018], http://wyborcza.pl/1,76842,7682242,Michal_ Sutowski Ryska_nie_da_sie_juz_upupic_html.

Tomasik Krzysztof (2014), Boy do sprawdzenia, [cyt. za: Prasa polska o książce Kapuściński non-fiction], w: Artur Domosławski, Kapuściński non-fiction, Wielka Litera, Warszawa, loc. 11692-11703.

Ziątek Zygmunt (2010), Biografia pisarza i „Kapuściński non-fiction”, „Odra”, nr 3, s. 64-72.

Żakowski Jacek (2010), Ta biografia nam pomoże, [online], [dostęp: 6 czerwca 2018], http://wyborcza.pl/1,75410,7623433,Jacek_ Zakowski_Ta_biografia_nam_pomoze.html.

Arleta Galant

Biographer, meaning who? The dispute over Kapuściński non-fiction The article reconstructs selected problems of critical and publicistic discussion around Artur Domosławski’s book Kapuściński non-fiction concerning the status of the biographical narrative, the role and duties of the biographer and the limits of biographical disclosures. The themes discussed in this sketch made it possible to indicate current issues related to workshop 
deficiencies and duties of the contemporary biographer, including the exposition of issues related to modernity, subjectivity and ethics of biographical undertakings.

Keywords: biography studies; book market; reception.

Arleta Galant - literaturoznawczyni, krytyczka literacka. Autorka książek Prywatne, publiczne, autobiograficzne (2010), Prowincje literatury. Polska proza kobiet po 1956 roku (2013-2014) oraz Zwroty krytyczne. Studia i szkice nie tylko o literaturze (2018). Współredaktorka kilku monografii dotyczących historii literatury kobiet, literatury najnowszej oraz współczesnej komunikacji literackiej; autorka artykułów poświęconych polskiej prozie, tekstom autobiograficznym, narracjom miejskim i feministycznej krytyce literackiej. Adres e-mail: arleta.galant@usz.edu.pl. 
